\title{
"KASUS PEMBUNUHAN HIRO DITINJAU DARI TEORI STRUKTUR TINDAKAN MANUSIA DAN TATANAN MORAL SUBJEKTIF"
}

\section{PAPER}

(Ditulis untuk memenuhi salah satu syarat kelulusan mata kuliah Etika Moral yang dibimbing oleh Bapak Agustinus W.Dewantara.S.S.,M.Hum)

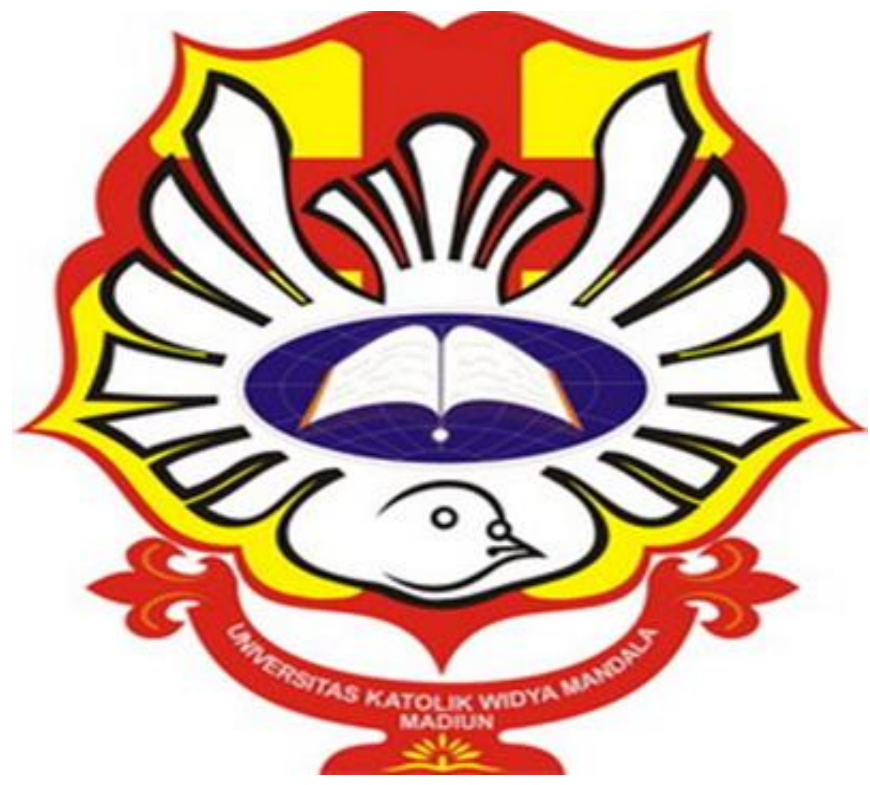

DISUSUN OLEH :

KUSPANITA

1843019001

FAKULTAS MIPA

PROGRAM STUDI BIOLOGI

UNIVERSITAS KATOLIK WIDYA MANDALA SURABAYA KAMPUS MADIUN 2019 


\section{KATA PENGANTAR}

Dalam nama Tuhan Yesus yang Maha Pengasih dan Maha Penyayang, saya tidak lupa memanjatkan segala puji dan syukur saya kepada-Nya karena atas berkat dan karunia-Nya saya bisa menulis dan menyelesaikan paper tentang kasus pembunuhan Melia yang disoroti dengan beberapa teori moral.

Paper ini saya tulis berdasarkan hasil wawancara saya sendiri dengan seorang teman yang pada waktu itu mengetahui pasti tentang kasus pembunuhan Melia tersebut. Sehingga dengan hasil wawancara itu saya bisa menulis paper ini dengan maksimal. Untuk itu saya sangat berterimakasih kepadanya yang telah berkontribusi memberikan informasi kepada saya dalam penulisan paper ini.

Saya juga tidak lupa mengucapkan terimakasih kepada dosen pembimbing mata kuliah Etika Moral yang telah memberikan saya tugas pembuatan paper ini karena dengan paper ini saya bisa menuliskan kasus pembunuhan Melia yang pada waktu itu masyarakat setempat tidak mengetahui siapa pelaku pembunuhannya dan masyarakat pun tidak mau melaporkan kejadian tersebut ke pihak polisi.

Terlepas dari segala hal tersebut saya sadar bahwa masih banyak kekurangan dalam penulisan paper ini baik dari segi tata bahasa maupun susunan kalimatnya. Oleh karena itu saya sangat mengharapkan saran dan keritik yang membangun dari pembaca, agar paper ini bisa menjadi lebih baik lagi. Saya juga berharap semoga dengan paper ini bembaca bisa meperoleh manfaat atau ispirasi untuk kebaikan hidup bersama di masa depan.

Madiun 23 Oktober 2019

Penulis 


\begin{abstract}
ABSTRAK
Hiro adalah seorang pemuda laki-laki buta yang pada waktu itu meniggal dunia tanpa diketahui, jasad Hiro ditemukan pada seminggu setelah kematiannya dalam keadaan sudah membusuk dan tidak bisa disentuh lagi pada sebuah bukit yang ada di tengah perkebunan kelapa sawit milik Swasta yang ada di Kalimantan Barat, dan tidak ada yang tahu pasti siapa pelaku pembuhnuhannya. Sebelum Hiro meninggal, malam itu Hiro dan beberapa anak muda serta Rino berkumpul di bukit untuk berpesta sambil minum-minuman keras juga. Namun sebelum itu Rino sempat menyerang Hiro lantaran sakit hati dan ingin balas dendam, dia sakit hati dengan Hiro yang sudah menutup jalan karena kayu yang digunakan Hiro untuk mentup jalan tersebut hampir mencelakai Rino. Dari cerita yang singkat ini setelah seminggu kemudia Hiro ditemukan sudah dalam keadaan setengah membusuk oleh seorang temannya di tempat kejadian dan langsung dimakamkan di tempat kejadian tersebut. Dari kejadian ini tidak ada pihak masyarakat yang mau melaporkannya ke pihak polisi. Maka dari paper ini bertujuan untuk mengetahui bagaimana moral dari kasus pembunuhan Hiro jika dilihat dengan menggunakan sudut pandang Struktur tindakan Manusia dan Tatanan Moral Subjektif.
\end{abstract}

\title{
Kata kuci : Hiro, actus humanus, Tatanan Moral Subjektif
}




\section{DAFTAR ISI}

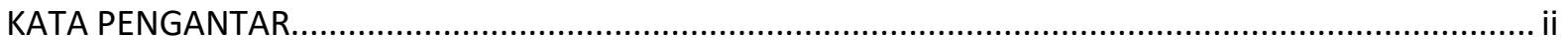

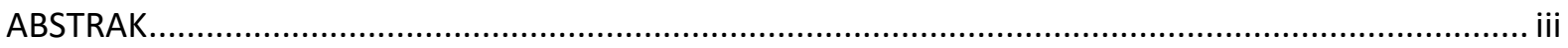

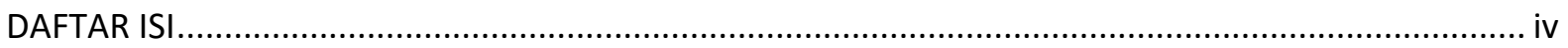

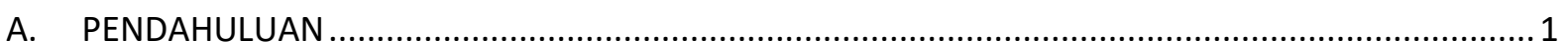

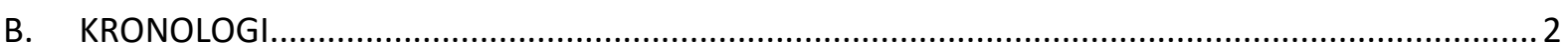

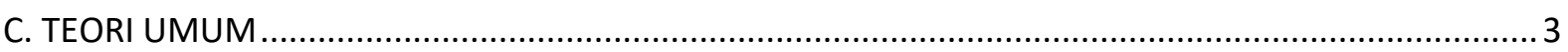

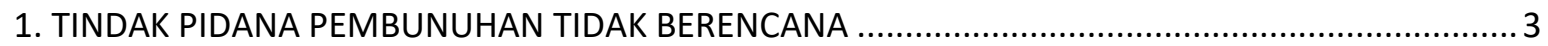

2. TINDAK PIDANA MEMBANTU/MENYEMBUNYIKAN JEJAK PELAKU KEJAHATAN ............................ 3

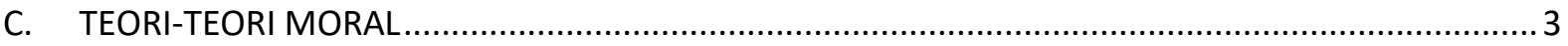

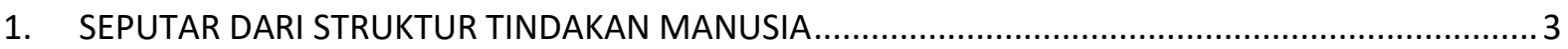

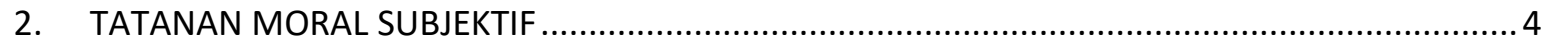

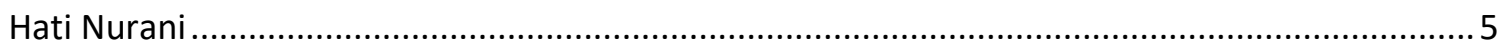

E. Kasus Pembunuhan Ditinjau dari Struktur Tindakan Manusia dan Tatanan Moral Subjektif......... 7

1. Kasus Hiro Ditinjau dari Struktur Tindakan Manusia ...........................................................

2. Kasus Pembunuhan Hiro Ditinjau dari Tatanan Moral Subjektif ............................................ 8

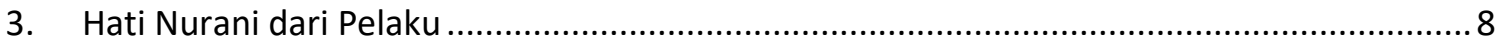

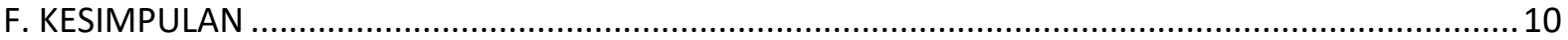

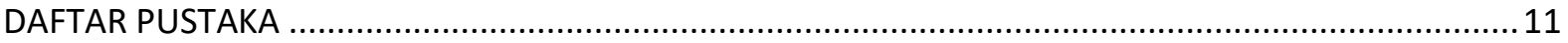




\section{A. PENDAHULUAN}

Tindakan kejahatan pembunuhan dengan cara-cara yang keji atau mengenaskan tidak hanya banyak terjadi kota-kota besar. Namun di desa yang sungguh masih sangat terkenal rasa kekeluargaan dan tolong-menolongnya juga bisa terjadi. Hal ini karena tindakan kejahatan sudah masuk kedalam tatanan kehidupan manusia. Bayak faktor yang membuat manusia melakukan tindakan kejahatan, masalah perekonomiaan dan kurangnya penghayatan terhadap nilai-nilai kehidupan dalam bermasyarakat menjadi motif utama terjadinya tindakan kejahatan. Tindakan kejahatan seperti pembunuhan, perampokan, pemerkosaan dan lain sebagainya tentu saja juga dipengaruhi oleh lemahnya nilai-nilai agama yang dipahaminya. Lemahnya nilai-nilai agama akan berpengaruh terhadap hati nurani manusia. Jika manusia mempunyai pegangan agamayang kuat, menjalankan perintah-Nya, menjauhi larangan-Nya, maka hal ini bisa menjadikan hati nurani manusia semakin tajam. Jika hati nurani manusia sudah tajam tentu saja dia bisa peka terhadap perbuatan mana yang baik dan mana yang buruk, karena seringnya mendapat siraman rohani dan imannya menjadi kuat. Namun tidak hanya itu, pengaruh minuman-minuman keras juga bisa membuat orang lebih rentan melakukan tindakan kejahatan hal ini karena minuman-minuman keras tersebut bisa mengendalikan berbagai macam tindakan manusia dengan alam setengah sadar. Berbeda halnya dengan mereka yang tidak beragama atau tidak mengenal tuhan. Walaupun tidak mengenal tuhan mereka masih bisa menjalankan oerbuatan baik karena karena ada bimbingan dari hati nurani yang dimiliki setiap individu. Namun bisa jadi hati nurani menjadi tumpul dan banhkan sesat. Maka dari ini saya tertarik untuk mengangkat 'Kasus Pembunuhan Hiro Ditinjau dari Teori Struktur Tindakan Manusia dan Tatanan Moral Subjektif” sebagai tema dari paper saya. 


\section{A. KRONOLOGI}

Hiro adalah seorang pemuda laki-laki buta yang pada waktu itu meniggal dunia tanpa diketahui, jasad Hiro ditemukan pada seminggu setelah kematiannya dalam keadaan sudah membusuk dan tidak bisa disentuh lagi pada sebuah bukit yang ada di tengah perkebunan kelapa sawit milik swasta yang ada di Kalimantan Barat, dan tidak ada yang tahu pasti siapa pelaku pembuhnuhannya. Namun sebelum Hiro meninggal, malam itu Hiro dan beberapa anak muda serta Rino berkumpul di bukit untuk berpesta sambil minum minuman keras juga. Sebelumnya, Rino sempat menyerang Hiro karena di tengah perjalanan Rino hampir terjatuh karena sepeda motor yang dinaikinya hampir saja menabrak kayu yang digunakan Hiro untuk menutup jalan di sebuah blok perkebunan kelapa sawit tersebut karena Hiro ingin menuntut pihak perusahaan tentang masalah tanah Hiro yang dijual ke perusahaan kelapa sawit tersebut belum selesai. Para anak muda yang ada di tempat kejadian pada waktu itu melarai perkelahian tersebut, alhasil merekapun berdamai kembali. Setelah itu merekapun lanjut berpesta sambil minum-minuman keras, malam pun sudah semakin larut karena sudah dimasuki alkohol, beberapa anak muda lainnya sudah pualng kerumah mereka masingmasing dan yang masih tinggal di tempat itu hanya Hiro dan Rino dan ternyata disitu Rino mendapat kesempatan lagi untuk menghabisi Hiro karena disitu hanya mereka berdua saja. Rino yang merupakan seorang buta dan sudah dalam posisi mabok karena minum-minuman keras tersebut tentu saja tidak bisa berdaya apa-apa saat dihajar oleh Rino dan akhirnya Hiro meninggal. Setelah itu tidak ada lagi yang pernah ketempat tersebut dan Hiro pun tidak ada pulang kerumahnya. Ketika teman Hiro rindu dengannya, dia mencari Hiro kerumahnya namun Hiro tidak ada di rumah, temannya tersebut mencari Hiro ke desa tetangga, karena biasanya Hiro kalau tidak ada di rumah terkadang menginap di desa tetangga. Tapi, setelah sampai di desa tersebut Hiro tidak ada di sana dan sudah beberapa hari juga orang-orang desa atau teman-teman Hiro yang lainnya tidak melihat Hiro. Lalu teman Hiro yang sedang mencari Hiro ini tiba-tiba kepikiran untuk mencari Hiro lagi di tempat terakhir dia ketemu Hiro, yaitu yakni di sebuah bukit yang ada di tengah perkebunan kelapa sawit milik swasta itu. Ketika sampai di sana, dia terkejut karena melihat Hiro yang terbaring di atas tanah dalam keadaan setengah membusuk karena ternyata Hiro meninggal sudah lama. Setelah melihat kejadian ini dia kembali lagi ke desa dan memberi tahu Kepala Desa setempat bahawa dia menemukan mayat Hiro sudah setengah membusuk di atas sebuah bukit di tengah perkebunan kelapa sawit yang letaknya tidak jauh dari desa tersebut. Melihat kejadian ini kepala desan dan para pengurus desa lainnya yang mengetahui bahwa si Hiro ini sudah tidak memiliki keluarga lagi maka mereka sepakat untuk memakamkan Hiro di atas bukit tersebut karena tubuh Hiro tidak bisa disentuh lagi. Setelah pemakaman Hiro selesai dilakukan ada beberapa teman Hiro yang ingin mengetahui secara pasti siapa pelaku dari pembunuhan tersebut berniat melaporkan kejadian ini ke pihak polisi. Namun si kepala desa meminta mereka sedikit bercerita karena dia belum mengetahui secara pasti kenapa Hiro meninggal di tempat itu dan sampai tidak ada yang mengetahui. Sesudah mendengar cerita dari beberapa anak muda tersebut Kepala Desa ini akhirnya menaruh dua kecurigaan bahwa Hiro meninggal karena dibunuh oleh Rino yang terakhir bersamanya Hiro malam itu atau Hiro meninggal karena terlalu banyak minum-minuman keras yang bercampur-campur. Ketika itu kepala desa tersebut meminta ketengan denga Rino yang terakhir bersama Hiro malam itu dan dari penjelsan yang diberikan Rino, dia mengaku bahwa memang benar pada 
awalnya dia berkelahi dengan Hiro dan malam itu yang terakhir bersama Hiro adalah dia, namun dia bersikeras menolak bahwa mereka menuduh dialah yang membunuh Hiro dan dia malah berusaha meyakinkan mereka bahwa Hiro meninggal karena keracunan minuman oplosan yang diminumnya terlalu banyak itu. Alhasi Kepala Desa pun menghentikan niat Teman Hiro yang ingin melaporkan kejadian ini ke pihak polisi

\section{TEORI UMUM}

\section{TINDAK PIDANA PEMBUNUHAN TIDAK BERENCANA}

Dalam KUHP Pasal 340 berbunyi: "Barang siapa dengan sengaja dan dengan rencana terlebih dahulu merampas nyawa orang lain, diancam karena pembunuhan dengan rencana, dengan pidana mati atau penjara seumur hidupatau selama waktu tertentu, paling lambat dua puluh tahun”. (Benedikt,2016)

\section{TINDAK PIDANA MEMBANTU/MENYEMBUNYIKAN JEJAK PELAKU}

\section{KEJAHATAN}

Pada Pasal 221 ayat (1) KUHP "Barang siapa dengan sengaja menyembunyikan orang yang melakukan kejahatan atau yang dituntut karena kejahatan, atau barang siapa memberi pertolongan kepadanya untuk menghindari penyelidikan atau penahanan oleh pejabat kehakiman atau kepolisian, atau orang lain yang menurut ketentuan undang-undang terus menerus atau sementara waktu diserahi menjalankan jabatan kepolisian”. (Aurelia,2019)

\section{B. TEORI-TEORI MORAL}

\section{SEPUTAR DARI STRUKTUR TINDAKAN MANUSIA}

Manusia bertindak dan harus bertindak. "Harus bertindak" artinya bahwa tindakan itu harus memenuhi standar atau kriteria normatif tertentu. Bahwa manusia bertindak, itu normal (sudah dengan sendirinya). Bertindak adalah ciri khas setiap makhluk hidup. Bahwa manusia "harus" bertindak, itu melukiskan eksistensi manusia secara mendalam, karena tindakan manusia tidak hanya berkaitan dengan eksistensinya sebagai makhluk hidup, melainkan juga mencetuskan nilai-nilai manusiawi. Makna terminologi "harus" mengedepankan pemahaman bahwa tindakan manusia harus memenuhi syarat moral atau etis tertentu.

Tindakan manusia adalah pencetusan dirinya. Jika disimak secara sepintas saja, jelas manusia secara konkret direprentasi dan ditentukan oleh tindakannya. Atau, autentisitas manusia sangat berurusan dengan perbuatannya. Maurice Blondel berkata bahwa tindakan manusia adalah representasi dirinya yang paling umum. Selain yang paling umum, tindakan manusia juga merupakan representasi dirinya yang paling lengkap. Dengan tindakannya, manusia menghadirkan dirinya secara memesonakan. Tindakan manusia ini secara garis besar bisa dibedakan menjadi dua yaitu; actus hominis dan actus humanus. 
1. Dalam actus hominis, tindakan manusia tampil sebagai suatu gerakan belaka. Artinya, actus hominis adalah suatu tindakan fisik yang dimiliki manusia dan dalam tindakan yang dilakukan manusia ini dia tidak sadar dengan apa yang dilakukannya karena tindakan ini jelas tidak menyertakan rasionalitasnya. Maka dalam tindakan ini manusia tidak berbeda dengan binatag karena manusia tidak mengedepankan kemanusiaannya. Jadi penilaian etis pun tidak dapat dilakukan kepadanya.

2. Berbeda halnya dengan actus humanus. Manusia yang merupakan makhluk cipataan tuhan yang memiliki akal budi yang tidak dimiliki oleh makhluk hidup lainnya. Hal inilah yang membuat manusia melakukan segala tindakan dan perbuatannya dengan syarat perbuatan moral. Artinya, perbuatan itu harus berada dalam bingkai konteks penilaian baik/buruk dan terpuji/tercela.

Actus humanus berkaitan erat dengan tahu, mau, dan bebas. Kebebasan ini mengandaikan dua hal yaitu bahwa manusia itu mengetahui dan menghendaki, dia disebut manusia bebas dan dengan itu dia bertanggung jawab atasnya. Tahu artinya selain mempunyai pengetahuan yang cukup terhadap objek perbuatannya, juga mengenali dengan baik siapa dirinya dan siapa objek dari tindakannya. kebebasan yang dimaksud ini tanpa unsur paksaan, namun menyangkut pilihanpilihan yang didepannya. Artinnya manusia mempunyai kebebasan dalam memilih dan menerapkan perkembangan baik dan buruk tentang pilihan yang akan diambil tersebut.

\section{TATANAN MORAL SUBJEKTIF}

Tatanan mamaksudkan dinamisme penilaian baik buruk dari suatu tindakan manusia dipahami pertama-tama sebagai urusan SUBJEK. Namun apabila suatu perbutan memiliki karakter subjektif, perbuatan tersebut masuk dalam kualifikasi moral. Contohnya seperti tindakan mencuri, tindakan mencuri ini bisa saja terdiri dari elemen-elemen yang kompleks. tindakan itu mengalir dari rentetan motivasi untuk melakukan pencuriaan. Dalam menegaskan motivasi, terdapat pula preferensi nilai atau gradasi pertimbangan baik buruk sampai kemudia tercetus keputusan untuk mencuri. Tetapi, keputusan mencuri belum termasuk perbuatan mencuri. Keputusan menjadi suatu perbuatan pada waktu kehendak mengeksekusinya dalam suatu tindakan. Jadi dalam tindakan mencuri, ada banyak elemen yang berpartisipasi di dalamnya: motivasi, kehendak, dan eksekusi kehendak dalam perbuatan. Mengenai perbutan manusia, kita bisa membedakan antara volition dan action. Volition berarti kehendak dalam arti tegas yang dapat masuk dalam kualifikasi baik buruk secara moral; dan action memaksudkan eksekusi atau pencetusan kehendak yang kita tampilkan dibawah kontrol kita. Antara kehendak (volition) dan perwujudannya (action) memang tidak bisa dipisahkan apabila suatu tindakan manusia dapat disebut sebagai tindakan lengkap. Tetapi, keduanya dapat dibedakan. 


\section{a. Hati Nurani}

Hati nurani dapat kita kenali secara fenomelogis, dari realitas bahwa manusia selaku melakukan pertimbanga-pertimbangan dalam hidupnya. Melakukan perimbangan artinya manusia memiliki semacam gradasi nilai-nilai yang menjadi fundamen untuk menegaskan pilihan-pilihan dalam melakukan keputusan. Hati nurani berarti hati manusia memiliki pengetahuan karena hati nurani ialah yang mengetahui. Namun kata mengetahui kurang tepat karena mengetahui berhubungan dengan akal budi atau rasio. Karena hati tidak bisa berfikir ( akal budi saja yang bisa berfikir), hati nurani sering kali disebut sebagai "suara Allah". Namun meskipun seseorang tidak mengenal Tuhan dan sabda-sabda-Nya, manusia tidak dapat melanggar perintah Tuhan karena dengan hati nuraninya Tuhan hadir didalam diri mereka. Tidak ada alasan bagi manusia yang tidak mengenal Allah untuk betindak sekenaknya, sebab mereka memiliki hati nurani yang dapat membibing perbuatan mereka. Fenomena hati nurani adalah fenomena pertimbangan boleh/tidak atau baik/buruk mengenai segala sesuatu yang dilakukan ole manusia. Hati nurani sepertinya mengajukan pradigma nilai-nilai moral yang disumberkan oleh Tuhan sendiri. Karena hati nurani adalah "suara Tuhan", aneka pertimbangan yang diberikannya mengantar manusia kepada Allah. Jadi, hati nurani tidak sekedar berurusan dengan salah benar secara etis, melainkan langsung menunjuk kepada relasi manusia dengan Allah dengan cara-cara yang tidak bisa direduksi sekedar dalam agama-agama formal.

\section{1) Hati Nurani Sesat}

Hidup manusia tidak hanya mengalir begitu saja, melainkan juga dibentuk oleh banyak faktor, seperti lingkungan sekitar, tradisi, peraturan, relasi kemanusiaan dengan yang lain. Apalagi apa yang disebut dengan hati nurani itu ialah kapasitas ke-elegan-an dalam diri manusiam. Artinya sejauh merupkan kapasitas, dia tidak bisa melepaskan diri dari konteks/ruang lingkup dimana manusia hidup/ada/menyejarah. Semuanya ini membangun konsep-konsep hati nurani manusia. St Thomas mengatakan bila kesesatan hati nurani tak bisa ditundukkan/tak bisa diatasi (invincible) dan tak bisa dipesalahkan/tak bisa dihukum (inculpable), orang dapat luput dari perbuatan yang secara moral jahat. Artinya bila ia berbuat jahat atas dorongan hatinya yang sesat invicible and inclupable, perbuatan jahatnya secara moral tidak bisa ditanggungkan keadaannya. Jika kesesatannya bisa diatasai (vincible) dan bisa dipersalahkan (culpable), tanggung jawab perbuatan buruk/jahatnya ada pada si pelaku.

Bila kesesatan hati nuraninya culpable and vincible, dia berdosa, baik apabila mengikuti suara hati nuraninya maupun tidak. Mengikuti suara hati nurani yang sesat cupable and vincible jelas salah, sebab perbuatan yang tercetus salah atau jahat. Kesesatan vincible adalah ketika subjek pada waktu itu dapat mengoreksinya. Ini berararti dia (subjek itu) memiliki kecurugaan-kecurigaan tertentu bahwa yang sedang dia lakukan itu tidak semestinya atau sewajarnya. Jadi, ada semacam kemungkinan untuk melakukan koreksi. Kalau kemungkinana itu sama sekali tidak ada, karena tidak tahu atau tidak memiliki relevansi moralitasnya, kesesatannya menjadi invincible. Kesesatan culpable adalah apabila itu merupakan produk dari pemanfaatan kebebasannya secara jahat, kesesatan vinceble tidak mesti merupakan 
sekaligus kesesatan culpable. Menjadi culpable apabila si pelaku bersikukuh atau bertahan atau sengaja membiarkan diri dalam kesesatannya. Dari sebab itu, mengenai hati nurani yang sesat yang culpable dan vincible, orang diminta untuk membenahi hidupnya dan tidak boleh menutup mata pada apa yang harus diketahuinya. Tidak bisa orang terus-menerus membiarkan diri pada perbuatan-perbuatan jelek. Kalaupun orang tidak diminta untuk mencetuskan desakan pada tindakan, dia tetap diminta untuk menyembuhkan hati nuraninya.

\section{2) Hati Nurani Bimbang}

Hati nurani bimbang berarti pengetahuannya tidak pasti. Hati nurani tidak pernah bimbang, karena jika bimbang orang tidak memiliki moralitas dari tindakannya. masalahnya adalah apakah yang harus dilakukan oleh seseorang apabila dia tidak mampu mengetahui dengan pasti apakah tindakan yang harus dilakukannya disaat ini, boleh tau tidak, wajib atau tidak ? dalam bimbingan rohani, bila dalam keraguan besar, jangan mengambil keputusan yang berhubungan dengan perkara yang besar. Bila hati nurani dalam kebimbangan, mereka tidak berada pada kondisi yang dapat dipertanggung jawabkan untuk melakukan perkaraperkara besar. Yang harus dilakukan mendandani dan memperbaiki kondisi hati nurani semacam ini. Kalau ragu-ragu, keragu-raguannya harus disembuhkan. Macam-macam keraguan (dubium): dubium iuris (ketidak tahuan yang berhubungan dengan hukum) dan dubium facti ( keraguan yang berhubungan dengan fakta). 


\section{E. Kasus Pembunuhan Ditinjau dari Struktur Tindakan Manusia dan Tatanan Moral Subjektif}

\section{Kasus Hiro Ditinjau dari Struktur Tindakan Manusia}

\section{a. Moral Pelaku Pembunuhan}

Berdasarkan teori actus humanus. Manusia yang merupakan makhluk cipataan tuhan yang memiliki akal budi yang tidak dimiliki oleh makhluk hidup lainnya. Namun dalam kasus pembunuhan tersebut Rino tidak mengunakan akal budinya secara benar. Hal inilah yang membuat Rino melakukan segala tindakan dan perbuatannya tanpa mempertimbangkan perbuatannya itu baik atau buruk terpuji atau tidak. Actus humanus yang berkaitan erat dengan tahu, mau, dan bebas sungguh sangat tidak dipertimbangkan Rino sebaik mungkin. Dalam kasus ini, perbuatan Rino sungguh tidak menunjukan perbuatan manusia sesungguhnya, jadi dimana letak akal budinya sampai membunuh orang buta hanya karena hal kecil ? lalu jika seperti itu, bagaimana hubungannya dengan tuhannya? tentu saja hubungannya dengan tuhan sungguh tidak baik, karena jika hubungannya dengan tuhanya baik tidak mungkin dia tega membunuh teman sendiri apalagi temannya ini adalah seorang buta yang sudah tidak memili keluarga lagi. Rendahnya nilai agama yang dimiliki Rino bisa langsung dilihat dari kehidupan sehari-harinya ini yang terkadang suka marah-marah dan berkelahi dengan orang-orang yang tidak disukainya atau dianggapnya salah dimatanya dan tindakan ini semua murni keluar dari dirinya sendiri sebagai manusia. Seharunya sebagai manusia yang berakal budi Rino terlebih dahulu melakukan rangkaian proses sebelum berindak yakni, merefleksi apa yang harus dilakukannya dan memikirkan terlebih dahulu apa konsekuensi dari perbuatan atau tindakannya tersebut. Jika hal ini dilakuakn maka akal budi mengarahkan menuju kebaikan. Karena sudah jelas diketahui kosekuensi pembunuhan ini tidak akan membuat hidup lebih tenang tentram dan sejahtera, yang ada malah fikiran selalu kacau, dan terbayang- bayang, selain itu juga dihantui dengan perasan dosa serta dikuikan dari kehidupan bermasyarakat karena dia sudah berbuat jahat dan keji seperti itu tetapi tidak mau mengaku dan tidak mau bertanggung jawab.

Berdasarkan teori-teori yang kita lihat di atas bahwa ada dua macam struktur tindakan manusia yaitu tindakan yang konsekuensinya tidak dikehendaki (directly voluntary) dan tindakan yang konsekuensinya dikehendaki (indirectly voluntary) setelah membaca kasus pembunuhan Hiro, kita tahu bahwa Rino sakit hati dengan Hiro dan merencanakan pembunuhan tersebut bukan karena unsur ketidak sengajaan. Walau kematian Hiro dikehendaki Rino, namun dalam pertimbangan moral tidak pernah boleh menghilangkan nyawa seseorang apalagi dengan cara sengaja yang masuk dalam golongan directly voluntary. Yang mempunyai tujuan baik saja tidak boleh melegitimasi sarana yang buruk, apalagi untuk tujuan buruk. dalam kasus ini motif pembunuhan adalah untuk balas dendam karena ulah Hiro, Rino hampir celaka, maka dari ini Rino membunuh Hiro agar dendam dan amarahnya bisa terbalas. Hal ini jelas tidak diperbolehkan. 


\section{a. Moral Teman-Teman Hiro}

Tidak haya moral pelaku pembunuhan, namun disini justru saya sangat tertarik juga untuk menyoroti moral dari teman-teman Hiro yang pada waktu itu tidak melanjutkan tuntutan mereka terhadap pelaku pumbunuhan tersebut, padahal mereka tahu bahwa berbuatan Rino ini jahat, perbuatan Rino ini sungguh tidak baik dan tidak terpuji. Seperti yang kita ketahui bahwa manusia sudah dianugrahi sebuah akal budi yang bisa digunakan untuk menuntun kehidupan bersama di masyarakat. Namun teman-teman Hiro juga pada waktu itu tidak menggunakan akal budi mereka dengan baik. Mungkin karena mereka masih remaja dan tidak berani melawan orang yang lebih tua dari mereka, sehingga mereka tidak meneruskan tuntutan tersebut. Dan bisa jadi juga relasi atau hubungan merekadengan tuhannya sungguh tidak baik juga karena jika hubungan mereka dengan tuhan mereka tidak mungkin membiarkan Rino tetap seperti orang yang tidak bersalah yang tidak seharusnya dimintai tanggung jawab karena sudah menghilangkan nyawa Hiro.

\section{Kasus Pembunuhan Hiro Ditinjau dari Tatanan Moral Subjektif}

Tindakan pembunuhan tidak hanya sekedar tindakan menghilangkan nyawa seseorang saja, namun banyak faktor-faktor yang mendasarinya. Seperti motivasi, kehendak, keterpaksaan, dan lainsebagainya yang menjadi dasar dari tindakan pembunuhan tersebut. Dalam kasus pembunuhan Hiro jelas terlihat bahwa adanya motivasi Rino untuk balas dendam terhadap Hirio yang waktu itu hampir menbuat Rino celaka. Dan untuk memenuhi hasrat balas dendamnya Rino waktu itu langsung menyerang Hiro, hanya saja perkelahian ini terhenti karena ada teman-teman Hiro yang melarai perkelahian tersebut. Namun setelah malam makin larut dan semua teman Hiro pulang, Rino pun mendapat kesempatan lagi untuk menghabisi nyawa Hiro. Tindakan Rino ini jelas- pasti dikatakan salah karena tidak seharunya dia membalas dendamnya terhadap Hiro yang seorang buta ini dengan cara membunuh atau menghilangkan nyawa Hiro.

\section{Hati Nurani dari Pelaku}

\section{a. Hati Nurani Sesat dari Pelaku}

Manusia yang merupakan makhluk ciptaan Tuhan yang paling sempurna jelas semuanya mempunyai hati nurani, meskipun mereka merasa dirinya tidak mempunyai Tuhan dan tidak mengenal Tuhan, namun mereka tetap tidak bisa melakukan perbuatan buruk dengan sesuka hatinya, karena didalam diri manusia sudah ada hati nurani yang menjadi kontrol untuk manusia berbuat dan bertindak. Tetapi jika kasus ini dikaitkan dengan hati nurani, Rino dikatakan memiliki hati nurani yang sesat. Tindakan yang dilakukan Rino untuk membalas dendamnya terhadap Hiro ini jelas adalah sebuah tindakan yang sesat. Hidup manusia pasti tidak jauh dengan faktor lingkungan dan relasi dengan sesama, seperti yang kita ketahui dalam kehidupan sehari-hari Rino yang sering marah-marah dengan orang-orang disekitarnya membuat dia tidak disukai oleh masyarakat setempat yang sudah mengetahui dengan jelas bagaimana perangai Rino ini. Jika hati nurani Rino tidak sesat tidak mungkin dia 
membuh Hiro yang merupakan seorang buta yang hidup tinggal sebatang kara tersebut. Maka dari itu Rino harus membenahi hidupnya, karena dia tidak boleh membiarkan hidupnya terusmenerusan tersesat dalam perbuatan atau tindakan jahat seperti itu. Dan penyembuhan hati nuranilah salah satu langkah awal untuk memperbaiki jalah kehidupan.

\section{b. Hati Nurani Bimbang dalam Diri Pelaku}

Selain dari hati nurani sesat yang dimiliki pelaku, dia juga memiliki hati nurani bimbang. Hal ini bisa kita lihat dari bagaimana dia menyembunyikan atau tidak mengakui perbuatannya itu, sehingga pada waktu dimintai keterangan oleh kepala desa dia malah menjawab tidak melakukan pembunuhan tersebut dan malah meyakinkan kepala desa dan teman- teman Hiro bahwa Hiro meninggal karena operdosis minuman keras yang diminumnya. Dan yang terjadi adalah semakin memudarnya nilai kebenaran dan kesejatian dalam dirinya. Ketakutan akan dipandang hina oleh warga desa membuat dia besikeras untuk tidak mengakui perbuatannya ini tanpa memikirkan konsekuensi yang sebenarnya yang akan terjadi di kehidupan akheratnya.

\section{c. Hati Nurani Bimbang dari Teman-Teman Hiro dan Kepala Desa}

Tidak hanya Rino sebagai si pelaku pembunuhan saja yang memiliki hati nurani yang bimbang. Namun teman-teman Hiro dan kepala desa tersebut juga memiliki hati nurani yang bimbang. Karena jika mereka tidak memiliki hati nurani yang bimbang tidak mungkin mereka membiarkan Rino terlepas begitu saja dari masalah ini. Seharunya mereka bisa membawa kasus ini kepolisi atau pihak yang berwajib agar kasus ini bisa terselesaikan dengan baik. Hal ini dilakukan dengan tujuan memberikan efek jera kepada Rino agar suatu saat nanti dia tidak lagi melakukan perbuatan atau tindakan yang sama. Serta supaya Rino bisa semakin memperbaiki akal budi dan hati nuraninya. Karena jika tidak seperti ini bisa saja nanti Rino melakukan hal yang sama lagi terhadap orang-orang di sekitarnya atau bahkan melakukan hal yang sama terhadap anak dan istrinya. Jika sudah terbiasa seperti itu pasti semua warga desa akan merasakan kesusahan juga. Dan tentu kasihan juga dengan Rino yang semakin lama hidupnya semakin tersesat. 


\section{F. KESIMPULAN}

Hidup itu pilihan, termasuk untuk menjadi manusia yang baik atau jahat itupun juga sebuah pilihan yang harus diambil. Namun sebaiknya ikutilah apa kata hati nurani agar hidup kita bisa berguna bagi diri sendiri dan sesama. Manusia memang tidak bisa luput dari kesalahan, tapi bukan berarti setiap kesalahan yang dilakukan oleh manusia itu harus dikatakan wajar, lalu tanpa adanya sangsi dari perbuatannya tersebut. Banyak hal duniawi yang membutakan manusia sehingga manusia terdorong untuk melakukan segala macam perbuatan buruk tanpa memikirkan sesamanya atau bahkan tanpa memkirkan bagai mana kehidupannya di dunia akherat nanti. Seperti pada kasus di atas jika kita melakukan perbuatan buruk tanpa mempertimbangkan konsekuensi terlebih dahulu, hasilnya akan menjadi tidak baik dan bahkan akan sangat merugikan. Maka dari kasus di atas kita dapat memetik nilai moralnya yaitu jika kita sering mengabaikan apa yang keluar dari hati nurani yang sering kita dengar dengan sebutan suara Tuhan maka, Tuhan akan memberikan teguran bisa secara langsung atau berupa peringatan. Seperti pada halnya Rino masih diberi kesempatan memperbaiki diri untuk menjadi pribadi yang lebih baik lagi. 


\section{DAFTAR PUSTAKA}

Cerita Kisah Nyata Rakyat di Kalimantan. (2018)

Dewantara, A. (2017). Filsafat Moral (Pergumulan Etis Keseharian Hidup Manusia).

Dewantara, A. W. (2019). RADIKALISME AGAMA DALAM KONTEKS INDONESIA YANG AGAMIS DAN BERPANCASILA. JPAK: Jurnal Pendidikan Agama Katolik, 19(1), $1-14$.

Dewantara, A. (2017). Diskursus Filsafat Pancasila Dewasa Ini.

Dewantara, A. W. (2015). Pancasila Sebagai Pondasi Pendidikan Agama Di Indonesia. CIVIS, 5(1/Januari).

Dewantara, A. W. (2017). Alangkah hebatnya negara gotong royong: Indonesia dalam kacamata Soekarno. PT Kanisius.

Dewantara, A. W. (2015). Pancasila Sebagai Pondasi Pendidikan Agama Di Indonesia. CIVIS, 5(1/Januari).

https://www.kompasiana.com/siagianbene/57cae2b40bb0bdb971401f4f/tindak-pidanapembunuhan-berencana-dan-penjelasan-pasal-340-kuhp

https://www.hukumonline.com/klinik/detail/ulasan/It54e72a65ae43d/sanksi-jika-membantumenghilangkan-jejak-pelaku-kejahatan/ 